\title{
A Gel Filtration Method for Determining Total Iron-Binding Capacity in Serum
}

\author{
By I. NIELSEN \\ From the Department of Clinical Biochemistry, Hjørring Central Hospital, Hjørring, Denmark
}

(Eingegangen am 18. September 1967)

\begin{abstract}
A method is described for determining the total iron-binding capacity of serum by gel filtration.
Excess iron is added to the serum to saturate the transferrin. The free iron is bound as ferroin in a complex with o-phenanthroline. Fractionation is then performed on a Sephadex G-25 column, and the iron in the serum effluent is determined with dipyridyl.

The method has the advantage that it utilizes the whole specimen thus requiring smaller serum samples. Furthermore it incorporates phenol as a deproteinising agent producing optically clear supernatants.
\end{abstract}

Es wird eine Methode für die Bestimmung der Gesamt-Eisen-Bindungskapazität des Serums durch Gelfiltration beschrieben.

$\mathrm{Zu}$ Serum wird Eisen in Uberschuß hinzugefügt, um das Transferrin zu sättigen. Das freie Eisen wird als Ferroin in einem Komplex mit o-Phenanthrolin gebunden. Die Fraktionierung wird dann an einer Sephadex-G-25-Säule durchgeführt und das Eisen im ausfließenden Serum mit Dipyridyl bestimmt.

Die Methode hat den Vorteil, daß sie die gesamte Probe verwertet und daher kleincre Serumproben benötigt. Ferner wird Phenol zum Enteiweißen benutzt; d̆as ergibt klare Überstände.

It is usual to determine and indicate the transferrin in serum indirectly by the maximum amount of iron which it can bind, the so-called total iron-binding capacity (TIBC).

As the degree of saturation of the transferrin is normally only about 0.30 , the first stage of a TIBC-determination consists of adding an excess of iron to total saturation, then removing the excess non-protein-bound iron prior to the final serum iron determination.

Among methods for removing the free iron are ion exchange (1), adsorption on magnesium carbonate (2), or binding in a complex (ferroin) with o-phenanthroline, which can then either be adsorbed on activated charcoal or precipitated by trichloroacetic acid (3).

Considering the molecular size it should be possible to separate protein-bound iron and electrolyte iron by means of a column of the highly cross-linked dextran, Sephadex G-25, using a bed volume 5-10 times the sample volume (4).

This principle was employed by BARBer, DempSTER and ANDERSON (5) in determining the unsaturated iron binding capacity (UIBC $=$ TIBC $\div$ actual $\mathrm{Fe}$ ): ${ }^{59} \mathrm{FeCl}_{3}$ .enriched serum was fractionated on a Sephadex column and the radioactivity in the eluate recorded continuously.

Contrary to expectation the elution diagrams from this study show that the free iron can only by separated sharply from the protein fraction by using the lower cross-linked dextran Sephadex G-50, and 4-5 times the theoretical hight of column. As a result the sample volume is diluted approximately 40 times. This is of no great significance in the traceer method, but it does have the result that the procedure is incompatible with a colorimetric determination of the iron. I have confirmed the elution pattern obtained by BARBER et al. (5).(fig. 1). A probable explanation of the discrepancy between theory and practice is that at the $\mathrm{pH}$ employed, 7.5, the iron behaves as a colloid, and is thus partly excluded from the gel. On the other hand, if the free iron is bound in a complex with :0-phenanthroline "by LAURELL's method (3), the sharp separation demanded by the theory is realized (fig. 2). The iron in the serum effluent can then be determined colorimetrically.

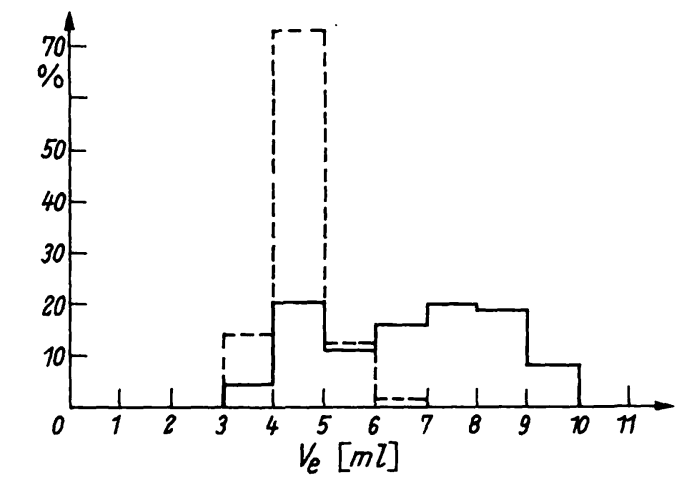

Fig. 1

Gel filtration on a Sephadex G-50 fine grade column of $10 \mathrm{ml}$ volume. $50 \mu \mathrm{g} \mathrm{Fe}$ was added to $1 \mathrm{~m} /$ normal serum

The effluent was sampled in $1 \mathrm{ml}$ fractions. The protein content (dotted line) and the iron content (continuous line) were determined and expressed as percent of the total amount Flow rate $5-6 \mathrm{ml}$ per hour
Tris-citrate buffer $\mathrm{pH} 7.5$

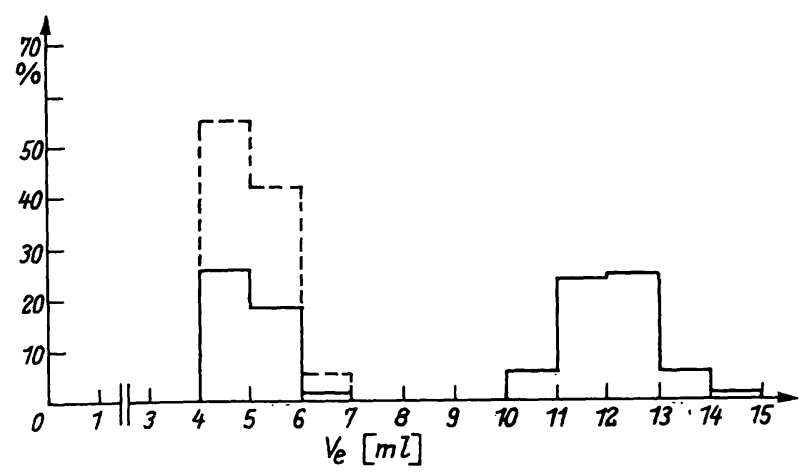

Fig. 2

Gel filtration on a Sephadex G-25 fine grade column of $10 \mathrm{ml}$ volume. $5 \mu \mathrm{g} \mathrm{Fe}$ was added to $1 \mathrm{~m} /$ normal serum, together with o-phenanthroline and sodium dithionite to permit the (free) iron to enter into the complex ferroin

The effluent was sampled in $1 \mathrm{ml}$ fractions. The protein content (dotted line) and the iron content (continuous line) were determined and expressed as percent of the total amount.
Flow rate $5-6 \mathrm{ml}$ per hour 


\section{Methods and materials}

The serum is enriched with iron in the presence of sodium dithionite. o-phenanthroline is then added, whereby the free iron forms ferroin, $\left(\mathrm{C}_{12} \mathrm{H}_{8} \mathrm{~N}_{2}\right)_{3} \mathrm{Fe}^{++}$(3).

This mixture is now fractionated by gel filtration. The iron conten of the serum effluent is then determined with dipyridyl according to the method of Ramsay (2) modified by the addition of phenol, which results in complete deproteinisation (6).

\section{Apparatus}

Columns, divided by a constriction of $3 \mathrm{~mm}$ inner diameter into a lower chamber, $10 \times 110 \mathrm{~mm}$ fitted with a capillary outlet with plastic tube, and an upper chamber, $15 \times 150 \mathrm{~mm}$ (7). The upper chamber is modified by means of a Quickfit air inlet adaptor to maintain a constant hydrostatic pressure.

Plastic tubes, $70 \times 11 \mathrm{~mm}$.

Plastic tubes, $100 \times 16 \mathrm{~mm}$ (Makrolon) + screw cap Roskilde,

Constriction pipettes, $50 \mu l$ and $1000 \mu l$.

Pipettes, $6.00 \mathrm{~m} /$ and $7.00 \mathrm{~m} /$.

Beckman DU spektrophotometer with $100 \mathrm{~mm}$ cell compartment for use with $50 \mathrm{~mm}$ half micro cuvettes.

\section{Reagents}

All chemicals are analytical grade.

Tris solution $25 \mathrm{~mm}$ : Tris(hydroxymethyl)aminomethane, $3.0 \mathrm{~g} / 1$.

Tris-citrate buffer $\mathrm{pH} 7.5$ : Tris(hydroxymethyl)aminomethane, $6.06 \mathrm{~g}$, citric acid $\left(1 \mathrm{H}_{2} \mathrm{O}\right), 2.85 \mathrm{~g}$, sodium chloride $5.80 \mathrm{~g}$, dissolved in deionised water to give a final volume of 1 liter.

Iron solution $1.8 \mathrm{~mm}$ : Iron(III)-chloride $\left(6 \mathrm{H}_{2} \mathrm{O}\right), 485 \mathrm{mg}, 5 \mathrm{~m} /$ $1 \mathrm{M}$ hydrochloric acid, and deionised water to give a final volume of 1 liter.

o-phenanthroline solution $16.8 \mathrm{~mm}$ : o-phenanthroline chloride $\left(\mathrm{H}_{2} \mathrm{O}\right) 39 \mathrm{mg}$, dissolved in $10 \mathrm{~m} /$ tris solution $25 \mathrm{~mm}$. This corresponds to a saturated solution of phenanthroline base.

Sodium dithionite solution $115 \mathrm{~mm}$ : Sodium dithionite $20 \mathrm{mg}$, dissolved in $1 \mathrm{~m} /$ Tris solution $25 \mathrm{~mm}$ prepared immidiately before use.

Dipyridyl-phenol solution, $19.2 \mathrm{~mm}$ and $530 \mathrm{~mm}$ respectively: 2,2-dipyridyl $3.0 \mathrm{~g}$, acetic acid $90 \mathrm{~m} /$, phenol $50 \mathrm{~g}$, dissolved in deionised water to give a final volume of 1 liter.

Sodium sulfite solution $300 \mathrm{~mm}$ : Sodium sulfite $3.8 \mathrm{~g}$, dissolved in deionised water to give a final volume of $100 \mathrm{~m} /$. Prepared daily.

Iron stock solution $1.79 \mathrm{~mm}$ : Iron wire $100 \mathrm{mg}$, dissolved in $50 \mathrm{~m} /$ concentrated hydrochloric acid and brought to 1 liter with deionised water.

Iron standard $53.7 \mu \mathrm{M}$ : Iron stock solution $30.00 \mathrm{~m} /$, brought to 1 liter with deionised water.

Sephadex G-25, fine.

\section{Packing the column}

The column is placed vertically in a stand, and the outlet covered with a perlon net, Monodur 45, corresponding to a mesh of $45 \mu \mathrm{m}$. The lower chamber is then filled with the eluent buffer, and the upper chamber filled with a suspension of Sephadex G-25 which has been allowed to swell in buffer for at least 24 hours. When the lower chamber is full, the superfluous Sephadex is removed and the column then stabilized by allowing buffer to run through (a volume $4-5$ times the bed volume). If the column settles during use, it is filled up again with the Sephadex suspension to the middle of the constriction.

\section{Procedure}

Serum sample

$1000 \mu \mathrm{l}$ of serum, $50 \mu \mathrm{l}$ of the iron solution ( $~ 5 \mu \mathrm{g}$ iron) and $50 \mu l$ of the sodium dithionite solution ( $\sim 1 \mathrm{mg}$ dithionite) are pipetted into a disposable plastic tube, $70 \times 11 \mathrm{~mm}$. After standing for $10 \mathrm{~min}$., $50 \mu \mathrm{l}$ of the o-phenanthroline solution is added, then the mixture is allowed to stand another 10 minutes. The mixture is then transferred to the Sephadex column by means of a $1000 \mu \mathrm{l}$ constriction pipette. While the sample is entering the gel bed, the effluent is allowed to run to waste. $7.00 \mathrm{~m} /$ tris-citrate buffer $\mathrm{pH} 7.5$ is then pipetted into the upper chamber which is thereafter fitted with an air inlet adaptor. The tip of this is placed about $1 \mathrm{~cm}$ above the constriction.

The effluent is collected in a makrolon tube, $110 \times 16 \mathrm{~mm}$, the flow being regulated to $5-6 \mathrm{~m} /$ per hour by raising and lowering the tip of the outlet tube.

A volume of $1000 \mu l$ dipyridyl-phenol solution and $1000 \mu l$ sodium sulphite solution are added to the effluent, and the makrolon tube is then fitted with a closely fitting screw cap and put in a boiling water bath for five minutes. After thorough cooling in running tap water, the tube is then centrifuged at $2000 \mathrm{~g}$ for $20 \mathrm{~min}$.

Standard

$1000 \mu l$ of the iron standard solution $+6.00 \mathrm{~m} /$ tris-citrate buffer $\mathrm{pH} 7.5$ receives the same treatment as the serum effluent.

\section{Reagent blank}

$7.00 \mathrm{~m} l$ tris-citratebuffer $\mathrm{pH} 7.5$ receives the same treatment as the serum effluent.

Readings are taken on a Beckman DU spectrofotometer at $522 \mathrm{~nm}$ in $50 \mathrm{~mm}$ half micro cuvettes.

The standard and the supernatant from the samples are read against the reagent blank, giving extinction $E_{s t}$ and $E_{p}$ respectively.

\section{Calculation}

$$
\operatorname{TIBC}=\frac{E_{p}}{E_{s t}} \cdot 53,7 \mu \mathrm{mol} / l\left(\frac{E_{p}}{E_{s t}^{-}} \cdot 3 \mathrm{mg} / l\right) .
$$

After elution of the protein from the column the upper chamber is filled with approximately $15 \mathrm{~m} l$ tris-citrate buffer. When this has almost all run through, and there is fluid at a height of about $0.5 \mathrm{~cm}$, the outlet tube is closed with a little plastic rod and the column can remain in this state until the next analysis.

\section{Results}

Normal value

Analysing the readings in 27 donors (16 men and 11 women) a mean value of $55.6 \mu \mathrm{mol} / l(3.10 \mathrm{mg} / \mathrm{l})$ was found with a standard deviation of $7.3 \mu \mathrm{mol} / l(0.41$ $\mathrm{mg} / \mathrm{l})$.

This agrees fairly well with the result obtained by LAURELL (3) who arrived at a mean value of $3.15 \mathrm{mg} / \mathrm{l}$, and a standard deviation of $0.33 \mathrm{mg} / \mathrm{l}$ in a total of $69 \mathrm{men}$ and 31 women. LAURELL found no grounds for assuming any sex difference.

\section{Precision}

The precision of the method is illustrated by calculating the standard deviation from the 27 double determinations using the formula $\sigma=\sqrt{\frac{\overline{\Sigma \mathrm{d}^{2}}}{2 \cdot \mathrm{n}}}$, where $\mathrm{d}$ is the difference between the respective double values, and $\mathrm{n}$ is the number of double determinations. $\sigma=1.8 \mu \mathrm{mol} / l$ ( $(0.10 \mathrm{mg} / \mathrm{l})$. This corresponds closely to the value found by the ion exchange method (8).

\section{Discussion}

In the determination of TIBC it is necessary to operate at a $\mathrm{pH}>7.2$ in order to avoid dissociation of the irontransferrin complex (3). So as not to fall lower than the 
critical pH on adding the acidic dithionite, LAURELL rcleased carbon dioxide from the serum by deep freezing for 24 hours, followed by thawing. In the present investigation the procedure followed was to buffer the reagent to $\mathrm{pH}$ approximately 7.5 by adding Tris, so that even fresh serum could be used without any risk.
The makrolon tubes supplicd arc packed in dust-tight containers and can be used immediatcly so that timeconsuming cleaning of glass ware is avoided.

The use of phenol results in a complete deprotcinisation during the heating and the supernatant is optically clear.

\title{
References
}

1. Hunkr, R. J., C. H. Sougl and N. Chinmori, Clin. chim. Acta (Amsterdnm) 3, 523 (1958). - 2. Ramsay, W. N. M., Clin. chim. Actn (Ansterdam) 2, 221 (1957). - 3. Laurzil., C.-B., Actn physiol. Scand., 14, suppl. 46 (1947). - 4. PI.ODIN, P., Dextran gels and their applications in gel filtration. 'Thesis, Uppsala (1962). 5. Barber, A., C. Demipster and N. Anderson, Clin. chim. Acta
(Amsterdam) 8, 143 (1963). - 6. London, M. Clin. Chem. New York 10, 789 (1964). - 7. PArruck, R. J., and R. E. THulers, Clin. Chem. New York 9, 283 (1963). - 8. Giovannibllo, 'Tir. J., and TH. Peters, Standard methods of clinical chemistry, $\mathrm{IV}^{r}$ p. 139. Hrsg. D. Scligson, Academic Press, New York (1963).

\section{Qualitative Veränderungen verschiedener jodierter phenolischer Aminosäuren im Laufe einer alkoholischen Extraktion aus wäßrigen Lösungen}

\author{
Von E. Zappr und G. Hoppls \\ Aus der 1. Mediziniscben Klinik des Städtiscben Auguste-Viktoria-Krankenhauses Berlin-Scljöneberg \\ (Direktor: Prof. Dr.K. H. Pfeffer)
}

(13ingegangen am 10. Oktober 1967)

Es werden die chemischen Veränderungen, die einige jodicrte phenolische Amninosäuren in Verlaufe ciner Extraktion aus wäßrigen Lösungen erfahren, untersucht. Dic durchgeführten chemischen und dünnschichtchromatographischen Kontrollen \%eigen, da $\beta$ dic prozentualen Verluste der $\Lambda$ usgangssubstanzen meistens relativ geringfügig sind. Die im Verlauf der Extraktion neugebildeten Verbindungen lassen sich, mit nur einer Ausnahme, als jodierte phenolische Aminosäuren identifizieren.

The qualitative changes which occur in a number of iodinated phenolic amino acids during alcoholic extraction from aqueous solutions, were investigated.

Thin-layer chromatographic controls showed that in most cases the decomposition of the starting matcrials is relatively sinall. The new compounds formed during the extraction can be classified, with one exception, as iodinated phenolic amino acids.

Aufgrund früherer Untersuchungen über dic Verteilungskocffizienten verschicdencr jodierter phenolischer Aminosäuren in ciner Reihe wäßrig-organischer Zweiphascn-Systeme (1) wurde eine Methode entwickelt, diese Substanzen aus dem Serum zu gewinnen. Die hohe Ausbeute ermöglicht nach weitergehender Rcinigung des Extraktes in Verbindung mit cinem jüngst beschricbenen dünnschichtchromatographischen System (2) die Trennung und Identifikation zirkulierender Schilddrüsenhormone und Derivate $(3,4)$.

Die Frage der eventuellen Zersetzung der jodierten Substanzen im Verlauf der Extraktion wird hier mittels rciner wäßriger Lösungen verschiedener Jodtyrosinc und Jodthyronine, die der Extraktion unterworfen wurden, näher untersucht. Dic Kontrollen wurden mit Hilfe der Dünnschichtchromatographic durchgeführt. Dic Anwendung einer relativ cinfachen Technik - auch hier beschrieben - gestattet die Auswertung der Intensität der vorhandenen Flecken auf den Chromatogrammen durch Extinktionsmessung.

\section{Methodik}

Als Versuchssubstanzen wurden folgende jodierte plienolische Aminosäuren verwendet: 3-Monojod- und 3,5-Dijod-L-Tyrosin, 3-Monojod-, 3,5-Dijod-, 3,3',5-Trijod- und 3,3',5,5'-Tetrajod-DLthyronin (MIT, DIT, $T_{1}, T_{2}, T_{3}, T_{4}$ ). Dicsc Substanzen wurden init $0,05 \mathrm{~N} \mathrm{NaOH}(0,5 \mathrm{mg}$ pro $\mathrm{m} /)$ gelöst und getrennt bearbeitet.

\section{Extraktionsverfaljren}

Dic Extraktion wurde folgendermaßen durchgeführt: $6 \mathrm{~m} / \mathrm{von}$ jeder der angesetzten Lösungen (glcich $3 \mathrm{mg}$ Versuchssubstanz) wurden in Zentrifugenröhrchen mit Schliff (ettva $65 \mathrm{~m} /$ Fassungsvermögen) mit $0,5 \mathrm{~m} / 1 \mathrm{M}$ Propylthiouracillösung verset/t, mit cinigen Tropfen konz. Essigsäure auf $\mathrm{pH}<5$ eingestellt und $5 \mathrm{Min}$. mit $15 \mathrm{~m} /$ Methanol an Rückflußkühler gekocht.

Dic wäßrig-alkoholische Phase wird nun mit $2 \mathrm{~g}$ eincr Mischung Natriumsulfat-Aktivkohle 200:1 geschüttelt, zentrifugicrt und nach Abtrennung des Rückstandes in cin anderes Schliffröhrchen überführt und am Rotationsverdainpfer bei Unterdruck und 55-60 eingeengt. Der Unterdruck wurde durch cine Wasserstrahlpumpe erecugt. Der trockene Rückstand wird mit $3 \mathrm{~m} / 0,05 \mathrm{~N} \mathrm{NaOH}$ aufgenommen und in ein Zentrifugenröhrchen mit einem Fassungsvermögen von ctwa $45 \mathrm{n} /$ gebrncht. Das vorherige Röhrchen wird mit $3 \mathrm{~m} / 0,05 \mathrm{~N}$ NaOH nachgespült und dieser Anteil mit dem andcren gemischt. Die wäßrige Lösung wird nach Kontrolle mit 